\title{
POST-HARVEST CONTROL OF APPLE BLUE MOLD UNDER COLD STORAGE CONDITIONS
}

\author{
${ }^{1}$ Ziad B. Al-Rawashdeh and ${ }^{2}$ Muwaffaq R. Karajeh \\ ${ }^{1}$ Plant Protection, Al-Shoubak College, \\ Al-Balqa’ Applied University, Al-Shoubak 71911, Jordan \\ ${ }^{2}$ Department of the Plant Protection and IPM, \\ Faculty of Agriculture, Mutah University, P.O. Box 7, Karak, 61710, Jordan
}

Received 2013-12-10; Revised 2014-01-19; Accepted 2014-01-23

\begin{abstract}
To control blue mold of apples caused by Penicillium expansum after harvest and during commercial cold storage, microwave exposure was investigated as a physical measure and compared with the use of calcium chloride and the systemic fungicide, carbendazime. Microwave exposure of Golden Delicious and Royal Gala apples at $2450 \mathrm{Mhz}$ for 10,30 and $45 \mathrm{~s}$ was effective as $4 \% \mathrm{CaCl}_{2}$ and carbendazime on significantly reducing the disease incidence $\%$. Calcium chloride was more effective at $8 \%$ than $4 \%$ or at $1 \%$ and was as effective as carbendazime in reducing the mold severity and incidence. Microwave exposure for 10, 30 and $45 \mathrm{~s}$ was as effective as $8 \% \mathrm{CaCl}_{2}$ and carbendazime on controlling blue mold caused by $P$. expansum stored under the conditions of commercial cold storage. Different apple cultivars have different degrees of susceptibility to the blue mold. Granny Smith and Red Delicious were relatively more tolerant than Golden Delicious, Starking or Royal Gala. However, sight variations were found in their responses to different treatments. Therefore, $10-45 \mathrm{~s}$ microwave exposure of apple fruits before cold storage alone or in a combination with other methods can be an environmental safe physical alternative to chemical fungicides for controlling $P$. expansum infections during cold storage.
\end{abstract}

Keywords: Calcium Chloride, Control, Penicillium Expansum, Microwave

\section{INTRODUCTION}

The domesticated apple (Malus $\times$ domestica Borkh.) is a main and common fruit crop in the world (Velasco et al., 2010). Consumers are increasingly demanding fruit of consistent high quality (Zeebroeck et al., 2007). Longterm cold storage of apples without significant loss of quality is greatly important (Deng et al., 2013). Postharvest losses of fruits and vegetables are high, ranging from 10 and $40 \%$ depending on the species and technologies used in the packinghouses (Arras and Arru, 1999; Wilson and Wisniewski, 1994). Higher risk of bacterial and fungal contamination could lower the shelflife of apple fruits during transportation and storage. Some qualitative and quantitative fruit losses are mainly due to pathogenic fungi which usually infect the host through wounds made during harvest, handling and processing (Wilson and Wisniewski, 1994). In apples, post-harvest losses are mainly due to blue mold caused by Penicillium expansum Link and grey mold caused by Botrytis cinerea Pers.: Fr. Penicillium expansum is a highly destructive pathogen that causes production losses during handling of the fruit (Sanzani et al., 2010) in form of post-harvest rots of pome fruits (Rosenberger et al., 1991). This pathogen is also a major producer of patulin, a mycotoxin which can reach high concentrations in infected apples and pears (Battilani et al., 2008) and has cytotoxic, genotoxic and immunosuppressive activities (Wouters and Speijers, 1996).

Despite the wide-spread use of modern storage facilities and techniques, synthetic chemical fungicides such as carbendazime, benomyl, iprodione, pyrimethanil ant Protection and IPM, Faculty of Agriculture, Mutah University, P.O. Box 7, Karak, 61710, Jordan 
and fludioxonil are frequently used immediately before or after harvest to control post-harvest molds of fruit (Eckert and Ogawa, 1988; Li and Xiao, 2008; Xiao et al., 2011). However, chemical control is increasingly limited because of environmental and toxicological risks as well as the onset of fungicide-resistant strains of fungal pathogens (Spotts and Cervantes, 1986; Delp, 1988; Holmes and Eckert, 1999). Moreover, the legal limits of chemical pesticide residues in imported fruit are much narrow in some countries, thus discouraging the use of pesticides. In the absence of safely effective post-harvest fungicides, alternative or integrative measures are becoming increasingly important in controlling postharvest diseases. To solve the problem of fungicide resistance and to fight against certain physiological disorders of apples and pears linked to calcium deficiency such as bitter pit, calcium chloride was used (Mason and Welsh, 1970; Perring, 1986; Raese and Stahly, 1988). Post-harvest calcium treatments can aid in helping the fruit to become more resistant to decay and were effectively used against blue mold of apples (Moline and Locke, 1993; Holmes and Eckert, 1999; Maouni et al., 2007). Biological control by antagonistic microorganisms is a promising tool for preventing post-harvest fungal rots and minimizing the use of fungicides (Janisiewicz and Korsten, 2002; Ippolito et al., 2004). However, biocontrol agents are sometimes not sufficient to control fungal infections when applied alone under practical conditions and their use should be integrated with other methods (Janisiewicz et al., 2003).

High frequency microwaves, when hit objects, can create heat (Wang and Tang, 2001). Microwave oven is widely used in food industry (Ikediala et al., 1999). Microwave exposure can directly affect living organisms due to its thermal effect on living tissue (Ondracek et al., 1976). Microwave treatments are widely used for drying, disinfesting and pasteurizing agricultural products while maintaining product quality and as a physical measure previously used effectively to control pests (Fanslow et al., 1975; Cunningham, 1980; Ikediala et al., 1999; Bol'shakov et al., 2001; Ernieenor and Ho, 2010). There are few reports (Karabulut and Baykal, 2002; Zhang et al., 2006) on the effect of microwaves as a post-harvest treatment for controlling blue mold of apples or even other diseases of post-harvest fruits. Therefore, this study aimed at investigating the utility of microwaves as a post-harvest treatment on blue mold of apples and comparing its effects with calcium chloride and carbendazime on different apple cultivars under cold storage conditions.

\section{MATERIALS AND METHODS}

\subsection{Pathogen Culture and Fruit Inoculation}

Penicillium expansum were isolated from decayed apples showing typical symptoms of blue mold. Spores of $P$. expansum were harvested with $10 \mathrm{~mL}^{-1}$ of sterile distilled water containing a drop of Tween 20. Spore counts were determined with a hemacytometer and adjusted with sterile distilled water to a 36000 spores $/ \mathrm{mL}$ concentration.

\subsection{First Experiment}

During the 2011 and 2012 growing seasons, apples (about $7 \mathrm{~cm}$-in-diameter) of two cultivars; Golden delicious was harvested at commercial maturity stage from an orchard conducted by the traditional crop management and kept at a refrigerator prior to use. Prior to treatment, apples were rinsed in tap water for $4 \mathrm{~min}$. Three fruits were placed in a clear and ventilated storage plastic container $\left(20 \times 30 \mathrm{~cm}^{2}\right)$. Five containers were set for each treatment thus each treatment was replicated five times. The following treatments were achieved; microwave exposure through placing one container containing three $P$. expansum-inoculated apple fruits in a $2450 \mathrm{Mhz}$ microwave oven (R-480J, SHARP® Sensor, Sharp corporation, Thailand) providing 1200 watt microwave power with a rotating platform (to insure uniform microwave exposure) for 10 and 30s or dipping the fruits of each container into a solution of calcium chloride at $10 \mathrm{~g} \mathrm{~L}^{-1}(1 \%)$ or $40 \mathrm{~g} \mathrm{~L}^{-1}(4 \%)$, carbendazime $50 \% \mathrm{WP}$ at $0.6 \mathrm{Ml} / \mathrm{L}$, or tap water (as untreated control). Blue mold disease incidence and severity $\%$ were assessed after cold storage for 4 weeks. Disease incidence was assessed as the number of decay spots of blue mold per apple fruit. Disease severity was measured as the proportion of decay lesion in the fruit and the following 0-5 scale was used; 0: no lesions, 1: 1-10, 2: 11-25, 3: 26-50, 4: 51-75, 5: 76-100\%, entire fruit decayed) and calculated as the sum of all numerical ratings per a treatment multiplied with $100 \%$ and divided on the multiplication of their total number with the maximum disease category (5).

\subsection{Second Experiment}

Three fruits of each apple cultivars; Golden Delicious, Red Delicious, Starking, Granny Smith and Royal Gala were placed in a clear and ventilated storage plastic container $\left(20 \times 30 \mathrm{~cm}^{2}\right)$. Five containers were set for each treatment thus each treatment was replicated five times. The following treatments were achieved; microwave exposure through placing one 
container containing three $P$. expansum-inoculated apple fruits in a $2450 \mathrm{Mhz}$ microwave oven for 10,30 and $45 \mathrm{~s}$ or dipping the fruits of each container into a solution of calcium chloride at $40 \mathrm{~g} \mathrm{~L}^{-1}(4 \%)$ and $80 \mathrm{~g}$ $\mathrm{L}^{-1}(8 \%)$, carbendazime $50 \% \mathrm{WP}$ at $0.6 \mathrm{~mL} \mathrm{~L}^{-1}$, or tap water (as untreated control). Blue mold disease incidence and severity \% were assessed after cold storage for 4 weeks. Disease severity and incidence were assessed as previously mentioned.

\subsection{Statistical Analysis}

Data were analyzed statistically using General Linear Model (GLM) procedure (SPSS software version 11.5; SPSS Inc., Chicago, USA). Least Significance Difference (LSD) test was used for mean separation at the 0.05 probability level. Significance of main factors and interactions was tested at the 0.05 probability level.

\section{RESULTS}

Results of the first experiment revealed a significant reduction of blue mold incidence on Golden Delicious fruit after 30s microwave exposure and carbendazime treatments followed by $10 \mathrm{~s}$ microwave exposure and $4 \%$ calcium chloride treatments used when compared with the untreated check while $1 \%$ calcium chloride treatment did obviously reduced the disease incidence (Fig. 1A). On other hand, all treatments except \% calcium chloride were able to reduce the disease severity significantly (Fig. 1B).

Results of the second experiment revealed that the 10 s exposure to microwave significantly gave the lowest reduction in blue mold disease severity and incidence in a similar level to the fungicide, Carbendazime. The other exposure times were also effective in reducing the disease amount (Table 1). Calcium chloride at $8 \%$ was obviously more effective than at $4 \%$ in suppressing the disease severity but with similar incidence on the different apple cultivars (Table 1 and 2). Among the apple cultivars, Granny Smith and Red Delicious had a significantly the lowest number of disease spots (Table 1) and the lowest disease severity \% (Table 2).

Both treatment and cultivar as main factors had significantly (Probability values $\leq 0.050$ ) affected the disease incidence and severity (Table 3 ). The treatment $\mathrm{X}$ cultivar interaction of them was significantly affected the severity of the blue mold (Table 3).

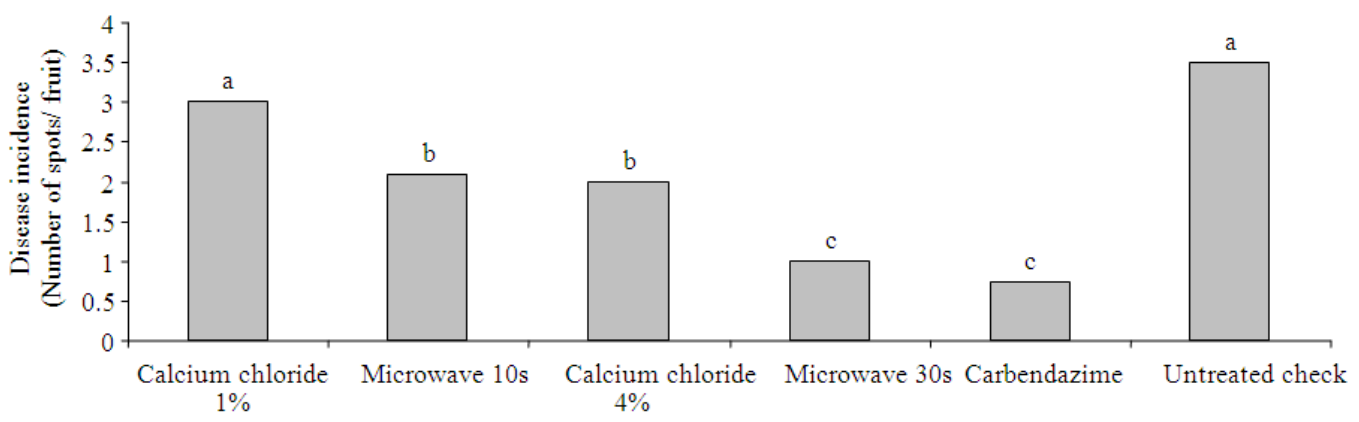

(A)

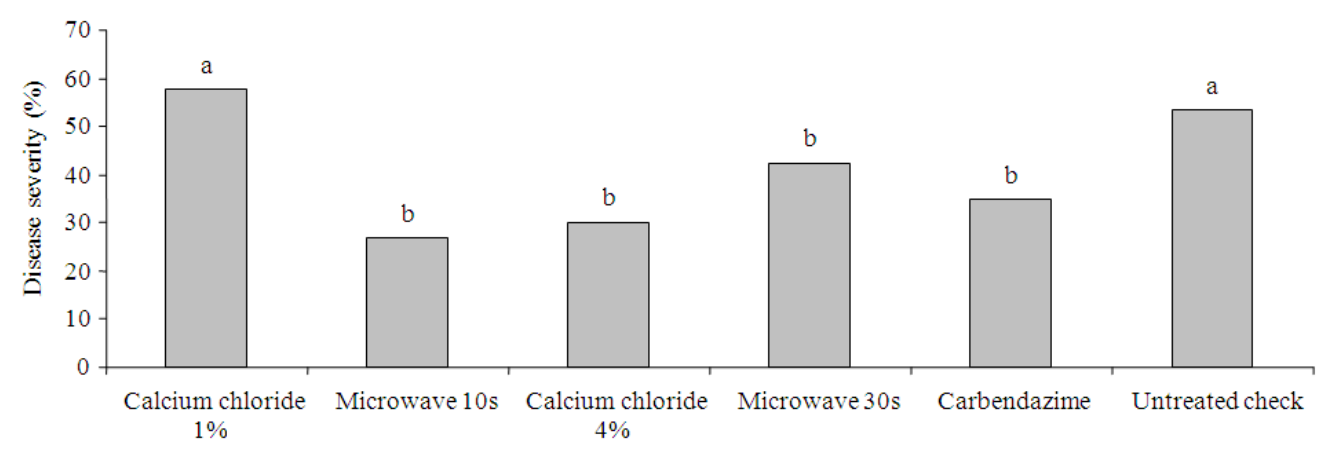

(B)

Fig. 1. Effects of different treatments used in the second experiment on blue mold disease incidence (A) and severity (B) on apple cv. Golden Delicious under cold storage conditions 
Table 1. Effects of different treatments on disease incidence $\%$ of blue mold on different apple cultivars

\begin{tabular}{|c|c|c|c|c|c|c|}
\hline \multirow[b]{2}{*}{ Treatment } & \multicolumn{6}{|l|}{ Cultivar } \\
\hline & Golden delicious & Red delicious & Starking & Granny smith & Royal gala & Means \\
\hline 10s microwave & $0.3^{1}$ & 1.0 & 0.0 & 0.3 & 1.0 & $0.5 \mathrm{~b}^{2}$ \\
\hline 30s microwave & 3.30 & 0.3 & 3.0 & 1.3 & 0.7 & $1.7 \mathrm{a}$ \\
\hline 45s microwave & 1.70 & 0.3 & 0.5 & 0.3 & 1.0 & $0.8 \mathrm{~b}$ \\
\hline $4 \% \mathrm{CaCl}_{2}$ & 1.60 & 1.0 & 2.3 & 1.0 & 0.0 & $1.2 \mathrm{ab}$ \\
\hline $8 \% \mathrm{CaCl}_{2}$ & 1.70 & 1.0 & 1.3 & 0.3 & 0.7 & $1.0 \mathrm{ab}$ \\
\hline Carbendazeme & 1.00 & 0.3 & 0.9 & 1.0 & 1.0 & $0.8 \mathrm{~b}$ \\
\hline Control & 2.80 & 1.0 & 1.0 & 0.3 & 2.0 & $1.4 \mathrm{ab}$ \\
\hline Means & $1.8 \mathrm{a}^{2}$ & $0.7 \mathrm{~b}$ & $1.3 \mathrm{ab}$ & $0.6 \mathrm{~b}$ & $0.9 \mathrm{ab}$ & \\
\hline
\end{tabular}

${ }^{1}$ Means of five replicates (2 fruits/container)

${ }^{2}$ Means within columns or rows followed by the same letter are significantly different at 0.05 probability level

Table 2. Effects of different treatments on disease severity $\%$ of blue mold on different apple cultivars

\begin{tabular}{|c|c|c|c|c|c|c|}
\hline \multirow[b]{2}{*}{ Treatment } & \multicolumn{6}{|l|}{ Cultivar } \\
\hline & Golden delicious & Red delicious & Starking & Granny smith & Royal gala & Means \\
\hline 10s microwave & 1.71 & 10.0 & 0.0 & 3.3 & 16.7 & $6.3 \mathrm{~cd}^{2}$ \\
\hline 30s microwave & 33.30 & 20.0 & 18.3 & 3.3 & 48.3 & $24.6 \mathrm{~b}$ \\
\hline 45s microwave & 23.30 & 3.3 & 50.0 & 16.7 & 7.8 & $20.2 \mathrm{~b}$ \\
\hline $4 \% \mathrm{CaCl}_{2}$ & 45.30 & 32.1 & 53.3 & 13.3 & 25.3 & $33.9 \mathrm{a}$ \\
\hline $8 \% \mathrm{CaCl}_{2}$ & 5.00 & 13.3 & 10.0 & 16.7 & 24.2 & $13.8 \mathrm{c}$ \\
\hline Carbendazeme & 3.30 & 5.0 & 0.0 & 10.0 & 13.3 & $6.3 \mathrm{~d}$ \\
\hline Control & 50.00 & 20.0 & 66.7 & 23.3 & 38.3 & $39.7 \mathrm{a}$ \\
\hline Means & $23.1 \mathrm{a}^{2}$ & $14.8 \mathrm{~b}$ & $28.3 \mathrm{a}$ & $12.4 \mathrm{~b}$ & $24.8 \mathrm{a}$ & \\
\hline
\end{tabular}

${ }^{\mathrm{T}}$ Means of five replicates (2 fruits/container)

${ }^{2}$ Means within columns or rows followed by the same letter are significantly different at 0.05 probability level

Table 3. Main and interaction effects of treatments and cultivar type on blue mold of apple under cold storage conditions

\begin{tabular}{lll}
\hline Source & Disease incidence & Disease severity \\
\hline Treatment & $0.003^{*}$ & 0.008 \\
Cultivar & 0.000 & 0.002 \\
Treatment X cultivar & 0.156 & 0.028 \\
\hline
\end{tabular}

*Probability values $\leq 0.050$ are significant

\section{DISCUSSION}

Fungal spores and latent infections of $P$. expansum are found either on the surface or in the first few cell layers under the peel of the fruit (Lurie, 1998). Postharvest treatment is very important since it can eliminate blue mold infections through removing spores from the fruit surface and acting directly on their viability and/or induce fruit defense mechanisms in the outer layers of the epicarp which reduce pathogen growth and development (Schirra et al., 2000).

Calcium chloride was more effective at 8 than 4 or at $1 \%$ and was as effective as carbendazime in reducing the mold severity and incidence. In vitro, $\mathrm{CaCl}_{2}$ had significantly little efficacy against $P$. expansum, even at
$6 \%$ while in vivo and at low temperature, it was effective at 4\% (Maouni et al., 2007). Compared to benomyl, 2\% $\mathrm{CaCl}_{2}$ was not effective in controlling $P$. expansum (Moline and Locke, 1993). As a mode of action, calcium ions might bind with intercellular pectic constituents of fruit tissue; which becomes resistant to the fungal pectolytic enzyme, polygalactouronase (Bateman, 1964; Conway et al., 1999). As a core ion of plant cell wall, calcium might increase the firmness of the treated fruit which may a benefit for permitting an extension of the fruit shelf life (Margosan et al., 1997; Sams et al., 1993).

In the present study, $2450 \mathrm{Mhz}$ microwave exposure for 10,30 and $45 \mathrm{~s}$ was as effective as $8 \% \mathrm{CaCl}_{2}$ and carbendazime on controlling blue mold caused by $P$. expansum in apples stored under the conditions of commercial cold storage. The mode of action of microwave on the blue mold may be due its direct effect on the conidia of $P$. expansum and indirectly by heating the surface of treated apple fruit to a temperature detrimental for $P$. expansum growth and development. A $2450 \mathrm{MHz}$ and 450 watt microwave exposure for 2 or 3 min of $P$. expansum-inoculated pear fruits was able 
effectively to reduce blue mold of pear without affecting fruit quality (Zhang et al., 2006).

The effectiveness of microwaves is exposure-time dependent. About $60 \%$ of the larvae of blow fly species, Chrysomya megacephala lived after $7 \mathrm{sec}$ of microwave exposure, most larvae died by $15 \mathrm{sec}$ and all larvae were dead at 30 and $60 \mathrm{sec}$ (Sripakdee et al., 2005). Fanslow et al. (1975) demonstrated that microwaves at $2450 \mathrm{MHz}$ destroy the eggs of the Southern corn rootworm, Diabrotica undecimpunctata. Microwaves at $460 \mathrm{MHz}$ can delay larval development in some insects, such as Drosophila melanogaster (Bol'shakov et al., 2001). Therefore, microwave exposure for certain duration time e.g., 10-45 sec may sufficiently be used as a post-harvest physical method of treating apple fruits of some tolerant cultivars e.g., Golden Delicious against the blue mold which is the most important post-harvest disease of apples.

Different apple cultivars have different degrees of susceptibility to the blue mold. Granny Smith and Red Delicious were relatively more tolerant than Golden Delicious, Starking or Royal Gala. However, sight variations were found in their responses to different treatments. Therefore, the use of microwave has feasible applicability for controlling apple blue mold.

Practically, as an instrument in commercial apple packing and cold storage houses, a $2450 \mathrm{Mhz}$ microwave oven can be mechanically set over a driving belt that usually used for grading apple fruits before packaging to provide at least 10s microwave exposure of apple fruits against post-harvest diseases e.g., blue mold and and can be thermostatically controlled using computer-based program (Mota et al., 2011; Srinivasan and Krishnan, 2012). Interestingly, the use of microwave is expected to be environmentally sound, durable, non-residual, easy to apply, cost and time effective non-chemical and nonbiological method when compared with the use of chemical fungicides, bioagents and mineral salts.

A combination of post-harvest methods could be more effective and consistent than the use of one method alone (Janisiewicz et al., 2003; Spadaro et al., 2004). Various alternative methods to fungicide application developed during the past decades were not commercially implemented or were implemented on a small scale because of insufficient mold control (Conway et al., 1999; Leverentz et al., 2000; Janisiewicz et al., 2003; Mclaughlin et al., 1990; Wisniewski et al., 1995; El-Ghaouth et al., 1994; Smilanick et al., 1999; Davila-Avina et al., 2011). Therefore, the use of microwaves could be combined with the application of other method e.g., $\mathrm{CaCl}_{2}$ to provide sufficient control of apple blue mold.

\section{CONCLUSION}

In a conclusion, 10-45s microwave exposure of apple fruits before cold storage alone or in a combination with other methods can be an environmental safe physical alternative to chemical fungicides for controlling blue mold of apple caused by $P$. expansum.

\section{REFERENCES}

Arras, G. and S. Arru, 1999. Integrated control of postharvest citrus decay and induction of phytoalexins by Debaryomyces hansenii. Adv. Hort. Sci., 13: 76-81.

Bateman, D.F., 1964. An induced mechanism of tissue resistance to polygalactouronase in Rhizoctonia infected hypocotyls of beans. Phytopathology, 54: 438-445.

Battilani, P., C. Barbano and A. Logrieco, 2008. Risk Assessment and Safety Evaluation of Mycotoxins in Fruits. In: Mycotoxins in Fruits and Vegetables, Barkai-Golan, R. and N. Paster, (Eds.), Academic Press, Amsterdam, ISBN-10: 0080557856.

Bol'shakov, M.A., I.R. Kniazeva, T.A. Lindt and E.V. Evdokimov, 2001. Effect of low-frequency pulsemodulated $460 \mathrm{MHz}$ electromagnetic irradiation on Drosophila embryos. Radiats Biol. Radioecol., 41: 399-402. PMID: 11605241

Conway, W.S., W.J. Janisiewicz, J.D. Klein and C.E. Sams, 1999. Strategy for combining heat treatment, calcium infiltration and biological control to reduce postharvest decay of 'gala' apples. Hort. Sci., 34: 700-704.

Cunningham, F.E., 1980. Influence of microwave radiation on psycrotrophic bacteria. J. Food Protection, 43: 651-655.

Davila-Avina, E.J., J. Villa-Rodriguez, R. CruzValenzuela, M. Rodriguez-Armenta and M. EspinoDiaz et al., 2011. Effect of edible coatings, storage time and maturity stage on overall quality of tomato fruits. Am. J. Agric. Biol. Sci., 6: 162-171. DOI: 10.3844/ajabssp.2011.162.171

Delp, C.J., 1988. Fungicide Resistance in North America. 1st Edn., APS Press, St. Paul, Minn, ISBN-10: 0890540950, pp: 133.

Deng, L., X. Pan, L. Chen, L. Shen and J. Sheng, 2013. Effects of preharvest nitric oxide treatment on ethylene biosynthesis and soluble sugars metabolism in 'Golden Delicious' apples. Postharvest Biol. Technol., 84: 9-15. DOI: 10.1016/j.postharvbio.2013.03.017 
Eckert, J.W. and J.M. Ogawa, 1988. The chemical control of postharvest diseases: Deciduous fruits, berries, vegetables and root tuber crops. Annul Rev. Phytopathol., 26: 433-469. DOI: 10.1146/annurev.py.26.090188.002245

El-Ghaouth, A., J. Arul, C. Wilson, A. Asselin and N. Benhamou, 1994. Ultrastructural and cytochemical aspects of the effect of chitosan on decay of bell pepper fruit. Physiol. Mol. Plant Pathol., 44: 417432. DOI: $10.1016 / \mathrm{S} 0885-5765(05) 80098-0$

Ernieenor, F.C.L. and T.M. Ho, 2010. Effects of microwave radiation on house dust mites, Dermatophagoides pteronyssinus and Dermatophagoides farinae (Astigmata: Pyroglyphidae). Southeast Asian J. Trop. Med. Public Health, 41: 1335-1341. PMID: 21329308

Fanslow, G.E., J.J. Tollefson and J.C. Owen, 1975. Ovicidal levels of $2.45 \mathrm{GHz}$ electromagnetic energy for the southern corn rootworm. J. Microwave Power, 10: 321-325. PMID: 1044338

Holmes, G.J. and J.W. Eckert, 1999. Sensitivity of Penicillium digitatum and P. italicum to postharvest citrus fungicides in california. Phytopathology, 89: 716-721. PMID: 18944698

Ikediala, J.N., J. Tang, L.G. Neven and S.R. Drake, 1999. Quarantine treatment of cherries using 915 $\mathrm{MHz}$ microwaves: Temperature mapping, codling moth mortality and fruit quality. Postharvest Biol. Technol., 16: 127-137. DOI: 10.1016/S09255214(99)00018-6

Ippolito, A., F. Nigro and L. Schena, 2004. Control of Postharvest Diseases of Fresh Fruits and Vegetables by Preharvest Application of antagonistic Microorganisms. In: Crop Management and Dris, R., R. Niskanen and Jain Sm, (Eds.), 1st Science Publishers, Enfield, ISBN-10: 157808279X.

Janisiewicz, W.J. and L. Korsten, 2002. Biological control of postharvest diseases of fruits. Annul Rev. Phytopathol., 40: 411-414. DOI: 10.1146/annurev.phyto.40.120401.130158

Janisiewicz, W.J., B. Leverentz, W.S. Conway, R.A. Saftner and A.N. Reed et al., 2003. Control of bitter rot and blue mold of apples by integrating heat and antagonist treatments on 1-mcp treated fruit stored under controlled atmosphere conditions. Postharvest Biol. Technol., 29: 129143. DOI: 10.1016/S0925-5214(03)00040-1
Karabulut, O.A. and N. Baykal, 2002. Evaluation of the use of microwave power for the control of postharvest disease of peaches. Postharvest Biol. Technol., 26: 237-240. DOI: 10.1016/S0925-5214(02)00026-1

Leverentz, B., W.J. Janisiewicz, W.S. Conway, R.A. Saftner and Y. Fuchs et al., 2000. Combining yeasts or a bacterial biocontrol agent and heat treatment to reduce postharvest decay of 'Gala' apples. Postharvest Biol. Technol., 21: 87-94. DOI: 10.1016/S0925-5214(00)00167-8

Li, H.X. and C.L. Xiao, 2008. Characterization of fludioxonil resistant and pyrimethanil resistant phenotypes of Penicillium expansum from apple. Phytopathology, 98: 427-435. DOI: 10.1094/PHYTO-98-4-0427

Lurie, S., 1998. Postharvest heat treatments. Postharvest Biol. Technol., 14: 257-269. DOI: 10.1016/S09255214(98)00045-3

Maouni, A., A. Lamarti, A. Aidoun, M. Khaddor and A. Badoc, 2007. Effect of benzimidazole fungicides and calcium chloride on Alternaria alternata and Penicillium expansum rot during storage of pears. Afr. J. Biotechnol., 6: 289-1292.

Margosan, D.A., J.L. Smilanick, G.F. Simmons and D.J. Henson, 1997. Combination of hot water and ethanol to control postharvest decay of peaches and nectarines. Plant Dis., 81: 1405-1409. DOI: 10.1094/PDIS.1997.81.12.1405

Mason, J.L. and M.F. Welsh, 1970. Cork spot (pit) of 'Anjou' pear related to calcium concentration in fruit. Hort. Sci, 5: 447-452.

Mclaughlin, R.J., M.E. Wisniewski, C.L. Wilson and E. Chalutz, 1990. Effect of inoculum concentration and salt solutions on biological control of postharvest diseases of apple with Candida sp. Phytopathology, 80: 451-456. DOI: 10.1094/Phyto-80-456

Moline, H.E. and J.C. Locke, 1993. Comparing neem seed oil with calcium chloride and fungicides for controlling postharvest apple decay. Hort. Sci., 28: 719-720.

Mota, A.A., L.T.M. Mota and C.C. Pezzuto, 2011. Object oriented modeling of thermostatically controlled devices for cold load pick-up. J. Comput. Sci., 7: 262-269. DOI: 10.3844/jcssp.2011.262.269

Ondracek, J., J. Zdarek and L.J. Datlov, 1976. Importance of antennae for orientation of insects in a non-uniform microwave electromagnetic field. Nature, 260: 522-523. DOI: 10.1038/260522a0 
Perring, M.A., 1986. Incidence of Bitter pit in relation to the calcium content of apples: Problems and paradoxes, a review. J. Sci. Food Agric., 37: 591-606. DOI: 10.1002/jsfa.2740370702

Raese, J.T. and E.A. Stahly, 1988. Timing of calcium sprays to increase fruit calcium, improve fruit quality and control disorders of "Anjou" pears. Hort. Sci.

Rosenberger, D.A., D.T. Wicklow, V.A. Korjagin and S.M. Rondinaro, 1991. Pathogenicity and benzimidazole resistance in Penicillium species recovered from flotation tanks in apple packinghouses. Plant Dis., 75: 712-715. DOI: 10.1094/PD-75-0712

Sams, C.E., W.S. Conway, J.A. Abbott, R.J. Lewis and N. Ben-Shalom, 1993. Firmness and decay of apple following postharvest pressure infiltration of calcium and heat treatment. J. Am. Soc. Hort. Sci., 118: 623-627.

Sanzani, S.M., L. Schena, A. De Girolamo, A. Ippolito and L. Gonzalez-Candelas, 2010. Characterization of genes associated with induced resistance against Penicillium expansum in apple fruit treated with quercetin. Postharvest Biol. Technol., 56: 1-11. DOI: 10.1016/j.postharvbio.2009.11.010

Schirra, M., G. Dhallewin, S. Ben-Yehoshua and E. Fallik, 2000. Host-pathogen interactions modulated by heat treatment. Postharvest Biol. Technol., 21: 71-85. DOI: 10.1016/S09255214(00)00166-6

Smilanick, J.L., D.A. Margosan, F. Milkota, J. Usall and I. Michael, 1999. Control of citrus green mold by carbonate and bicarbonate salts and the influence of commercial postharvest practices on their efficacy. Plant Dis., 83: 139-145. DOI: 10.1094/PDIS.1999.83.2.139

Spadaro, D., A. Garibaldi and M.L. Gullino, 2004. Control of Penicillium expansum and Botrytis cinerea on apple combining a biocontrol agent with hot water dipping and acibenzolar-S-methyl, baking soda, or ethanol application. Postharvest Biol. Technol., 33: 141-151. DOI: 10.1016/j.postharvbio.2004.02.002

Spotts, R.A. and L.A. Cervantes, 1986. Populations, pathogenicity and benomyl resistance of Botrytis spp., Penicillium spp. and Mucor piriformis in packinghouses. Plant Dis., 70: 106-108. DOI: 10.1094/PD-70-106
Srinivasan, M. and A. Krishnan, 2012. Hot resistance estimation for dry type transformer using multiple variable regression, multiple polynomial regression and soft computing techniques. Am. J. Applied Sci., 9: 231-237. DOI: 10.3844/ajassp.2012.231.237

Sripakdee, D., K.L. Sukontason, S. Piangjai, R. NgernKlun and K. Sukontason, 2005. Effect of microwave irradiation on the blow fly Chrysomya megacephala (F.) (Diptera: Calliphoridae). Southeast Asian J. Tropical Med. Public Health, 36: 893-895. PMID: 16295541

Velasco, R., A. Zharkikh, J. Affourti, A. Dhingra and A. Cestaro et al., 2010. The genome of the domesticated apple (Malus $\times$ domestica Borkh.). Nature Genet., 42: 833-841. DOI: 10.1038/ng.654

Wang, S. and J. Tang, 2001. Radio frequency and microwave alternative treatments for insect control in nuts: A review. Agric. Eng. J., 10: 105-120.

Wilson, C.L. and ME. Wisniewski, 1994. Biological Control of Postharvest Diseases: Theory and Practice. 1st Edn., CRC Press, Boca Raton, pp: 182.

Wisniewski, M.E., S. Droby, E. Chalutz and Y. Eilam, 1995. Effect of Ca2+ and Mg2+ on Botrytis cinerea and Penicillium expansum in vitro and on the biocontrol activity of Candida oleophila. Plant Pathol., 44: 1016-1024. DOI: 10.1111/j.13653059.1995.tb02660.x

Wouters, M.F.A. and G.J.A. Speijers, 1996. Toxicological evaluations of certain food additives and contaminants: Patulin. WHO Food Addit. Ser, 35: 377-402.

Xiao, C.L., Y.K. Kim and R.J. Boal, 2011. First report of occurrence of pyrimethanil resistance in Penicillium expansum from stored apples in Washington State. Plant Dis., 95: 72-72. DOI: 10.1094/PDIS-07-100509

Zeebroeck, V.M., V.V. Linden, H. Ramon, J.D. Baerdemaeker and B.M. Nicola et al., 2007. Impact damage of apples during transport and handling. Postharvest Biol. Technol., 45: 157-167. DOI: 10.1016/j.postharvbio.2007.01.015

Zhang, H.Y., X.D. Zheng and D.M. Su, 2006. Postharvest control of blue mold rot of pear by microwave treatment and Cryptococcus laurentii. J. Food Eng., 77: 539-544. DOI: 10.1016/j.jfoodeng.2005.06.066 